\title{
Accepting Uncertainty: The Work of Special Educators in a Pandemic
}

\author{
Laura Medwetz \\ University of St. Thomas \\ Chientzu Candace Chou \\ University of St. Thomas
L. Lynn Stansberry Brusnahan
University of St. Thomas

School closures in March 2020 due to COVID-19 affected over one billion students worldwide (UNESCO, 2020). Stay-home orders issued across multiple regions required schools to shift to a distance learning model for the remainder of the school year. We examined the experiences of special educators in one midwestern state as they managed and adapted their work during the onset of the pandemic. Participants across a variety of locations and programs responded to the statewide survey. This article discusses how teachers provided specialized programming by utilizing multiple instructional models, including fully online instruction and more traditional paper packets. In addition, participants described a variety of approaches for interacting with colleagues and families to ensure continuous special education programming while attending to health pandemic restrictions. The findings from this study present gaps in instructional technology and digital communication for students. This article goes deeper by examining how special educators coped with the unprecedented changes in their professional work and their lifestyles to reveal teachers' positive coping approaches.

Keywords: distance learning, special education programming, health pandemic, coping

\section{INTRODUCTION}

School closures in March 2020 due to the Coronavirus Disease -19 (COVID-19) affected over one billion students worldwide (UNESCO, 2020). Multiple barriers surfaced as districts worked to support student access to educational programming through distance learning (Hartshore et al., 2020). Despite school district guidance, special education teachers reported difficulty providing intensive intervention and support services to students requiring individualized education program (IEP) plans. This study examined the work of special education teachers (SETs) in Minnesota as they managed and adapted their work during pandemic conditions. The unprecedented demands and increased workload during COVID-19 placed SETs at an increased risk of experiencing high stress levels. This study also analyzed the coping styles of special educator's adjusting to complex work. 


\section{LITERATURE REVIEW}

Due to school closings, teachers shifted their duties and responsibilities from the classroom to primarily online instruction without substantial training (Cavanaugh \& Deweese, 2020). Distance learning required new instructional technologies never used with certain age groups or disability areas. Although teachers required training in using technology in the classroom, they also need time to apply new skills to their teaching practice (Cavanaugh \& Deweese, 2020). The rapid change to a fully online program presented a widespread problem of practice.

School and family partnerships are critical to the success of online programming for students with disabilities (Coy, 2014; Currie-Rubin \& Smith, 2014). Depending on the child's age and the severity of the disability, SETs rely on parents to support their students in navigating the variety of digital tools used in fully online learning environments and in assignment modification (Coy, 2014; Currie-Rubin \& Smith, 2014). Students with disabilities need more opportunities to talk about their work, seek assistance, and get the necessary feedback to persist in online schoolwork (Rice \& Greer, 2014). Distance learning required new approaches, including new forms of interaction (Cavanaugh \& Deweese, 2020; Trust et al., 2020).

During the COVID-19 school closures, the workload for teachers increased (Gudmundsdottir \& Hathaway, 2020). Much of the necessary work for SETs is managing paperwork and communicating with colleagues, parents, and other student team members (Vannest \& Hagan-Burke, 2010). SETs leave the profession due to stress, lack of administrative support, high workloads, dissatisfaction, lack of understanding of the role, and the variability of support in mentoring and induction (Billingsley et al., 2004; Hagaman \& Casey, 2017; Whitaker, 2000). In their beginning years of teaching, SETS experience reduced energy levels and less engagement in work resulting in high levels of stress and burnout (Bettini et al., 2018). Unfortunately, many teachers leave the field due to high stress levels (Hagaman \& Casey, 2017).

Due to the mandates of social distancing during COVID-19, teachers had to make changes in their work while isolated from their professional community and forced to solely interact with others using virtual platforms (Trust et al., 2020). To develop practical approaches for professional development, it is essential to learn more about the support and resources SETs accessed through online services (Cavanaugh \& Deweese, 2020; Gudmundsdottir \& Hathaway, 2020). Examining how SETs adapted to their work and dealt with the continuous shifts is instrumental in understanding what steps are needed to retain special educators and support effective educational programming for all students.

\section{BACKGROUND}

Minnesota classroom instruction was abruptly interrupted in spring 2020 by governor orders (Governor Walz Executive Order 20-02) for a school closure period due to COVID-19 health concerns. During the brief closure period, districts and schools quickly shifted typical face-to-face instruction to distance learning. Governor-issued orders (Exec. Order 20-19, 2020) followed to implement distance learning for the remainder of the school year. The Minnesota Distance Teaching and Learning Implementation Guidance (MDE, 2020) document defined distance learning as student access to "appropriate educational materials and daily interaction with their licensed teacher(s)" (p. 5). For students requiring intensive intervention and support, the state issued a guiding document for distance learning and implementing a multi-tiered system of support (MDE, 2020). The framework required daily contact and academic engagement between teachers, students, and parents (MDE, 2020). Minnesota teachers rapidly transitioned to online learning as the primary form of instruction. However, the Minnesota Department of Education (2020) allocated instructional materials as a distance learning method to supplement or replace e-learning or online learning (p. 5). Some students received hard copy instructional packets delivered to the home or available for parent pick up at the school. 


\section{RESEARCH METHODS}

In this study, researchers disseminated an anonymous survey through Minnesota special education listservs to examine the following research question: How did Special Education Teachers (SETs) describe the impact of the 2020 Coronavirus Disease -19 (COVID-19) pandemic on the way they provide special education service? We collected quantitative data from surveys to study how SETs provided instruction, interacted with students and parents/guardians, and how they coped with the work during spring, 2020 distance learning. The researchers also gathered data on what resources were helpful to special educators in their work.

\section{Participants and Settings}

Minnesota licensed special educators $(\mathrm{N}=198)$, either provisionally licensed SETs $(7 \%)$ or fully licensed SETS (93\%), self-volunteered to complete the anonymous survey mid-April through mid-June 2020. The years of teaching experience ranged from one year through ten or more years of experience, although most $(83 \%)$ participants had six or more years of teaching experience. Slightly more than half of the SETs (54\%) taught students with mild to moderate disabilities, 34\% taught students with moderate to severe disabilities, and $11 \%$ taught students identified with severe to profound disabilities. The age and grade level of their students ranged from birth to five years old (12\%), elementary primary level (24\%), elementary intermediate level (25\%), middle school and high school $(35 \%)$ and transition-age (3\%). The participants taught across a variety of Minnesota locations, including schools in the city (27\%), suburbs (31\%), towns (23\%), rural (16\%), and across multiple demographic settings (4\%). Participants self-reported demographics on the survey (see Table 1).

TABLE 1

PARTICIPANT DEMOGRAPHICS

\begin{tabular}{|l|l|l|l|l|}
\hline Gender & $\begin{array}{l}\text { Years of } \\
\text { Experience }\end{array}$ & $\begin{array}{l}\text { School / District } \\
\text { Location }\end{array}$ & $\begin{array}{l}\text { Age / Grade } \\
\text { Level }\end{array}$ & Severity of Disability \\
\hline Female $(\mathrm{n}=185)$ & $\begin{array}{l}0 \text { to 1 Years } \\
(\mathrm{n}=6)\end{array}$ & Rural $(\mathrm{n}=30)$ & $\begin{array}{l}\text { Birth to age 5 } \\
(\mathrm{n}=24)\end{array}$ & $\begin{array}{l}\text { Mild to Moderate } \\
(\mathrm{n}=107)\end{array}$ \\
\hline Male $(\mathrm{n}=12)$ & $\begin{array}{l}2 \text { to 3 Years } \\
(\mathrm{n}=18)\end{array}$ & Town $(\mathrm{n}=45)$ & $\begin{array}{l}\text { Elementary K-5 } \\
(\mathrm{n}=101)\end{array}$ & $\begin{array}{l}\text { Moderate to Severe } \\
(\mathrm{n}=72)\end{array}$ \\
\hline Unknown $(\mathrm{n}=1)$ & $\begin{array}{l}4 \text { to 5 Years } \\
(\mathrm{n}=9)\end{array}$ & Suburb $(\mathrm{n}=64)$ & $\begin{array}{l}\text { Middle/High } \\
\text { School }(\mathrm{n}=68)\end{array}$ & $\begin{array}{l}\text { Severe to Profound } \\
(\mathrm{n}=19)\end{array}$ \\
\hline & $\begin{array}{l}6 \text { to 9 Years } \\
(\mathrm{n}=29)\end{array}$ & City $(\mathrm{n}=52)$ & Transition $(\mathrm{n}=5)$ & \\
\hline & $\begin{array}{l}\text { Over 10 Years } \\
(\mathrm{n}=136)\end{array}$ & Other $(\mathrm{n}=7)$ & & \\
\hline
\end{tabular}

\section{Data Analysis}

The researchers analyzed the survey responses using a statistical software platform (IBM SPSS Statistics) to condense data and identify participant self-rated responses by valid percentages. Survey data included how SETs provided instruction, interacted with students and parents, and completed due process work such as Individualized Education Program plans. Data also included what SETs considered as helpful resources.

Most participants $(\mathrm{N}=186)$ also self-volunteered to respond to items on coping by completing the Brief COPE (Carver, 1997). The Brief COPE (Carver, 1997) is 28-item validated research-based assessment measuring 14 differentiated coping reactions (e.g., active coping, planning, positive refraining, selfdistraction, denial). Researchers analyzed participant responses to identify the most frequent coping styles and least used coping styles used by SETs during distance learning. 


\section{FINDINGS}

Survey data attended to the work of SETs during the governor mandated stay home order due to the onset of the COVID-19 pandemic. The findings describe how SETs conducted their work while also adapting to the changes required for distance learning. We describe the findings related to two main themes: (1) the distance learning work of SETS and (2) coping with the changes of distance learning work.

\section{The Distance Learning Work of Special Educators}

Given the mandated stay at home orders, teachers worked from their homes. Teachers used a variety of methods to reach their students and families in a distance learning setting. The survey directed participants to identify all the approaches they used during this time; therefore, a cumulative percentage is not provided in Tables $2-5$. The findings describe the most prevalent or least approaches, however participants may have used a combination of approaches as well.

Participants used a variety of instructional formats as noted in Table 2. Most (78\%) of the participants met with students individually using synchronous virtual platforms (e.g., Zoom or Google Meet). Slightly more than half $(59 \%)$ of the participants delivered printed materials to a students' home or emailed instructional materials (53\%) to their students. Instructional methods used by less than half of the participating SETs included synchronous group instruction (45\%), asynchronous individual instruction (45\%), asynchronous group instruction (39\%), and providing printed instructional materials for parents to pick up at the school (35\%).

TABLE 2

\section{DISTANCE LEARNING FORMATS USED}

\begin{tabular}{|l|l|}
\hline Type of Format: Instructional & Valid Percentage \\
\hline Synchronous - individual & $78 \%$ \\
\hline Synchronous - group & $45 \%$ \\
\hline Asynchronous - individual & $45 \%$ \\
\hline Asynchronous - group & $39 \%$ \\
\hline Instructional materials - emailed & $53 \%$ \\
\hline Printed materials - picked up & $35 \%$ \\
\hline Printed materials - delivered & $59 \%$ \\
\hline
\end{tabular}

Given the educational needs of students in special education programming, SETs needed to interact and communicate with both their students and the parents or guardians of their students. Online instructional platforms (88\%) were the most used approach for communicating. Email (87\%) communication was also readily used. In addition, participating SETs commonly used the phone to interact with parents and their students. Phone use included traditional phone interaction $(81 \%)$ and the texting feature by over half of the participants (69\%). The U.S. mail was used the least (38\%). Table 3 presents the variety of formats used by participants to interact with students and/or parents. 
TABLE 3

METHODS OF INTERACTION WITH STUDENTS AND PARENTS/GUARDIANS

\begin{tabular}{|l|l|}
\hline Type of Format: Interaction/Communication & Valid Percentage \\
\hline Online platform & $88 \%$ \\
\hline Email & $87 \%$ \\
\hline Phone & $81 \%$ \\
\hline Text & $69 \%$ \\
\hline U.S. Mail & $38 \%$ \\
\hline Other & $16.70 \%$ \\
\hline
\end{tabular}

Completing the special education legal processes and documentation is another responsibility of SETs. During the spring 2020 governor issued stay home orders, special education teams still needed to complete necessary paperwork or due process work to adhere to the legal requirements of special education programming. The Individualized Education Program (IEP) plan outlines the special education services and specific educational goals for the student. The IEP plan is a binding legal document requiring annual adjustment and when services change. Noted in Table 4, participants primarily used virtual or online platforms $(93 \%)$ to complete IEP plan requirements with student special education team members. During the pandemic stay home orders, most special educators $(70 \%)$ used email to share paperwork. Special educators corresponded using the phone (49\%), U.S. mail (26\%) and text (13\%) to complete required IEP plan work.

TABLE 4

METHODS FOR COMPLETING IEPS

\begin{tabular}{|l|l|}
\hline Type of Format: IEPs & Valid Percentage \\
\hline Online Platform & $93 \%$ \\
\hline Email Paperwork & $70 \%$ \\
\hline Phone & $49 \%$ \\
\hline Text & $13 \%$ \\
\hline U.S. Mail & $26 \%$ \\
\hline Other & $5 \%$ \\
\hline
\end{tabular}

Due to the mandates of social distancing during COVID-19, teachers made changes in their work while isolated from their professional community. Yet SETs continued to rely on the support of their immediate colleagues for resources. As noted in Table 5, over half (54\%) of the participants identified immediate team/colleagues as the most helpful resource, while less (19\%) considered the school district or school helpful. Professional teaching organizations or media and social networking educational groups (e.g., Facebook) were regarded as helpful by far less participants (10\% and 12\%).

TABLE 5

\section{HELPFUL RESOURCES}

\begin{tabular}{|l|l|}
\hline Type of Resource & Valid Percentage \\
\hline Immediate team/colleagues & $54 \%$ \\
\hline School district/school & $19 \%$ \\
\hline Social networking education groups (e.g., Facebook) & $12 \%$ \\
\hline Professional teaching organizations or media & $10 \%$ \\
\hline
\end{tabular}




\section{Coping With the Changes of Distance Learning Work}

Participants responded to 28 items on coping, indicating how they had been dealing with stress since distance learning went into effect. Each item presented something about a particular way of coping. Participants responded whether they had been doing what the prompt indicated, rather than if they thought the approach was an effective way to cope with the COVID-19 school changes. Table 6 presents participant responses to items using a four-point Likert scale, one as "I haven't been doing this at all" and four as "I've been doing this a lot". Participant responses were analyzed within the 14 Brief Cope (1994) coping styles, using the relevant prompts for each of the coping styles. By combining participant ratings of three and fourpoints, percentages are presented for each of the 14 coping styles to present the prevalence of each style.

\section{TABLE 6 COPING STYLES}

\begin{tabular}{|c|c|c|c|c|c|}
\hline Coping Style (Carver, 1997) & 1 & 2 & $\beta$ & 4 & $\begin{array}{l}3 \& 4 \\
\text { Combined }\end{array}$ \\
\hline Acceptance & & & & & $87 \%$ \\
\hline $\begin{array}{l}\text { Q20. I've been accepting the reality of the fact } \\
\text { that it has happened. }\end{array}$ & $\begin{array}{l}2.2 \% \\
(4)\end{array}$ & $\begin{array}{l}11.3 \% \\
(21)\end{array}$ & $\begin{array}{l}47.8 \% \\
(89)\end{array}$ & $\begin{array}{l}38.7 \% \\
(72)\end{array}$ & \\
\hline Q24. I've been learning to live with it. & $\begin{array}{l}.5 \% \\
(1)\end{array}$ & $\begin{array}{l}11.8 \% \\
(22)\end{array}$ & $\begin{array}{l}62.9 \% \\
(117) \\
\end{array}$ & $\begin{array}{l}24.7 \% \\
(46)\end{array}$ & \\
\hline Active Coping & & & & & $66 \%$ \\
\hline $\begin{array}{l}\text { Q2. I've been concentrating my efforts on doing } \\
\text { something about the situation I'm in. }\end{array}$ & $\begin{array}{l}9.1 \% \\
(17)\end{array}$ & $\begin{array}{l}34.4 \% \\
(64)\end{array}$ & $\begin{array}{l}41.9 \% \\
(78)\end{array}$ & $\begin{array}{l}14.5 \% \\
(27)\end{array}$ & \\
\hline $\begin{array}{l}\text { Q7. I've been taking action to try to make the } \\
\text { situation better. }\end{array}$ & $\begin{array}{l}3.8 \% \\
(7)\end{array}$ & $\begin{array}{l}21.5 \% \\
(40) \\
\end{array}$ & $\begin{array}{l}53.8 \% \\
(100)\end{array}$ & $\begin{array}{l}21 \% \\
(39) \\
\end{array}$ & \\
\hline Positive Reframing & & & & & $65 \%$ \\
\hline $\begin{array}{l}\text { Q12. I've been trying to see it in a different light, } \\
\text { to make it seem more positive. }\end{array}$ & $\begin{array}{l}4.3 \% \\
(8)\end{array}$ & $\begin{array}{l}32.3 \% \\
(60)\end{array}$ & $\begin{array}{l}48.4 \% \\
(90)\end{array}$ & $\begin{array}{l}15.1 \% \\
(28)\end{array}$ & \\
\hline $\begin{array}{l}\text { Q17. I've been looking for something good in } \\
\text { what is happening. }\end{array}$ & $\begin{array}{l}2.7 \% \\
(5)\end{array}$ & $\begin{array}{l}30.1 \% \\
(56)\end{array}$ & $\begin{array}{l}47.3 \% \\
(88)\end{array}$ & $\begin{array}{l}19.9 \% \\
(37)\end{array}$ & \\
\hline Self-Distraction & & & & & $65 \%$ \\
\hline $\begin{array}{l}\text { Q1. I've been turning to work or other activities } \\
\text { to take my mind off things. }\end{array}$ & $\begin{array}{l}4.3 \% \\
(8)\end{array}$ & $\begin{array}{l}33.9 \% \\
(63)\end{array}$ & $\begin{array}{l}35.5 \% \\
(66)\end{array}$ & $\begin{array}{l}26.3 \% \\
(49)\end{array}$ & \\
\hline $\begin{array}{l}\text { Q19. I've been doing something to think about it } \\
\text { less, such as going to movies, } \\
\text { watching TV, reading, daydreaming, sleeping, or } \\
\text { shopping. }\end{array}$ & $\begin{array}{l}5.4 \% \\
(10)\end{array}$ & $\begin{array}{l}25.8 \% \\
(48)\end{array}$ & $\begin{array}{l}43.0 \% \\
(80)\end{array}$ & $\begin{array}{l}25.8 \% \\
(48)\end{array}$ & \\
\hline Planning & & & & & $58 \%$ \\
\hline $\begin{array}{l}\text { Q14. I've been trying to come up with a strategy } \\
\text { about what to do. }\end{array}$ & $\begin{array}{l}5.4 \% \\
(10) \\
\end{array}$ & $\begin{array}{l}30.1 \% \\
(56)\end{array}$ & $\begin{array}{l}47.3 \% \\
(88)\end{array}$ & $\begin{array}{l}17.2 \% \\
(32)\end{array}$ & \\
\hline $\begin{array}{l}\text { Q25. I've been thinking hard about what steps to } \\
\text { take. }\end{array}$ & $\begin{array}{l}10.8 \% \\
(20)\end{array}$ & $\begin{array}{l}37.6 \% \\
(70)\end{array}$ & $\begin{array}{l}39.2 \% \\
(73)\end{array}$ & $\begin{array}{l}12.4 \% \\
(23)\end{array}$ & \\
\hline Using Emotional Support & & & & & $56 \%$ \\
\hline $\begin{array}{l}\text { Q5. I've been getting emotional support from } \\
\text { others. }\end{array}$ & $\begin{array}{l}4.8 \% \\
(9)\end{array}$ & $\begin{array}{l}34.9 \% \\
(65)\end{array}$ & $\begin{array}{l}44.1 \% \\
(82)\end{array}$ & $\begin{array}{l}16.1 \% \\
(30)\end{array}$ & \\
\hline $\begin{array}{l}\text { Q15. I've been getting comfort and understanding } \\
\text { from someone. }\end{array}$ & $\mathrm{g}\left(\begin{array}{l}8.6 \% \\
(16)\end{array}\right.$ & $\begin{array}{l}39.8 \% \\
(74)\end{array}$ & $\begin{array}{l}37.6 \% \\
(70)\end{array}$ & $\begin{array}{l}14.0 \% \\
(26)\end{array}$ & \\
\hline
\end{tabular}

Note: 1 = I haven't been doing this at all; 2 = I've been doing this a little bit; 3 = I've been doing this a medium amount; $4=$ I've been doing this a lot 


\begin{tabular}{|c|c|c|c|c|c|}
\hline Coping Style (Carver, 1997) & 1 & 2 & 3 & 4 & \begin{tabular}{|l}
$3 \& 4$ \\
Combined
\end{tabular} \\
\hline Religion & & & & & $43 \%$ \\
\hline $\begin{array}{l}\text { Q22. I've been trying to find comfort in my } \\
\text { religion or spiritual beliefs. }\end{array}$ & $\begin{array}{l}25.3 \% \\
(47)\end{array}$ & $\begin{array}{l}32.3 \% \\
(60)\end{array}$ & $\begin{array}{l}23.1 \% \\
(43)\end{array}$ & $\begin{array}{l}19.4 \% \\
(36)\end{array}$ & \\
\hline Q27. I've been praying or meditating. & $\begin{array}{l}24.7 \% \\
(46)\end{array}$ & $\begin{array}{l}31.2 \% \\
(58)\end{array}$ & $\begin{array}{l}26.3 \% \\
(49)\end{array}$ & $\begin{array}{l}17.7 \% \\
(33)\end{array}$ & \\
\hline Using Instrumental Support & & & & & $42 \%$ \\
\hline $\begin{array}{l}\text { Q10. I've been getting help and advice from } \\
\text { other people. }\end{array}$ & $\begin{array}{l}19.4 \% \\
(36)\end{array}$ & $\begin{array}{l}34.4 \% \\
(64)\end{array}$ & $\begin{array}{l}33.3 \% \\
(62)\end{array}$ & $\begin{array}{l}12.9 \% \\
(24)\end{array}$ & \\
\hline $\begin{array}{l}\text { Q23. I've been trying to get advice or help from } \\
\text { other people about what to do. }\end{array}$ & $\begin{array}{l}14.0 \% \\
(26)\end{array}$ & $\begin{array}{l}48.9 \% \\
(91)\end{array}$ & $\begin{array}{l}27.4 \% \\
(51)\end{array}$ & $\begin{array}{l}9.7 \% \\
(18) \\
\end{array}$ & \\
\hline Humor & & & & & $32 \%$ \\
\hline Q18. I've been making jokes about it. & $\begin{array}{l}21.5 \% \\
(40)\end{array}$ & $\begin{array}{l}38.2 \% \\
(71)\end{array}$ & $\begin{array}{l}28.5 \% \\
(53)\end{array}$ & $\begin{array}{l}11.8 \% \\
(22)\end{array}$ & \\
\hline Q28. I've been making fun of the situation. & $\begin{array}{l}37.6 \% \\
(70)\end{array}$ & $\begin{array}{l}39.2 \% \\
(73)\end{array}$ & $\begin{array}{l}17.2 \% \\
(32)\end{array}$ & $\begin{array}{l}5.9 \% \\
(11) \\
\end{array}$ & \\
\hline Venting & & & & & $27 \%$ \\
\hline $\begin{array}{l}\text { Q9. I've been saying things to let my unpleasant } \\
\text { feelings escape. }\end{array}$ & $\begin{array}{l}32.3 \% \\
(60)\end{array}$ & $\begin{array}{l}48.9 \% \\
(91)\end{array}$ & $\begin{array}{l}15.6 \% \\
(29)\end{array}$ & $\begin{array}{l}3.2 \% \\
(6)\end{array}$ & \\
\hline Q21. I've been expressing my negative feelings. & $\begin{array}{l}14.5 \% \\
(27)\end{array}$ & $\begin{array}{l}50.0 \% \\
(93)\end{array}$ & $\begin{array}{l}30.1 \% \\
(56)\end{array}$ & $\begin{array}{l}5.4 \% \\
(10) \\
\end{array}$ & \\
\hline Self-Blame & & & & & $17 \%$ \\
\hline Q13. I've been criticizing myself. & $\begin{array}{l}30.1 \% \\
(56)\end{array}$ & $\begin{array}{l}42.5 \% \\
(79)\end{array}$ & $\begin{array}{l}18.3 \% \\
(34)\end{array}$ & $\begin{array}{l}9.1 \% \\
(17)\end{array}$ & \\
\hline $\begin{array}{l}\text { Q26. I've been blaming myself for things that } \\
\text { happened. }\end{array}$ & $\begin{array}{l}84.9 \% \\
(158)\end{array}$ & $\begin{array}{l}9.1 \% \\
(17) \\
\end{array}$ & $\begin{array}{l}4.3 \% \\
(8)\end{array}$ & $\begin{array}{l}1.6 \% \\
(3)\end{array}$ & \\
\hline Denial & & & & & $8 \%$ \\
\hline Q3. I've been saying to myself "this isn't real.". & $\begin{array}{l}59.1 \% \\
(110)\end{array}$ & $\begin{array}{l}28.0 \% \\
(52)\end{array}$ & $\begin{array}{l}9.1 \% \\
(17)\end{array}$ & $\begin{array}{l}3.8 \% \\
(7)\end{array}$ & \\
\hline $\begin{array}{l}\text { Q8. I've been refusing to believe that it has } \\
\text { happened. }\end{array}$ & $\begin{array}{l}82.8 \% \\
(154) \\
\end{array}$ & $\begin{array}{l}14.5 \% \\
(27)\end{array}$ & $\begin{array}{l}1.6 \% \\
(3) \\
\end{array}$ & $\begin{array}{l}1.1 \% \\
(2) \\
\end{array}$ & \\
\hline Behavioral Disengagement & & & & & $6 \%$ \\
\hline Q6. I've been giving up trying to deal with it. & $\begin{array}{l}60.2 \% \\
(112)\end{array}$ & $\begin{array}{l}33.3 \% \\
(62)\end{array}$ & $\begin{array}{l}5,4 \% \\
(10)\end{array}$ & $\begin{array}{l}1.1 \% \\
(2)\end{array}$ & \\
\hline Q16. I've been giving up the attempt to cope. & $\begin{array}{l}78.0 \% \\
(145)\end{array}$ & $\begin{array}{l}17.2 \% \\
(32)\end{array}$ & $\begin{array}{l}4.3 \% \\
(8)\end{array}$ & $\begin{array}{l}.5 \% \\
(1) \\
\end{array}$ & \\
\hline Substance Use & & & & & $4 \%$ \\
\hline $\begin{array}{l}\text { Q4. I've been using alcohol or other drugs to } \\
\text { make myself feel better. }\end{array}$ & $\begin{array}{l}71.5 \% \\
(133)\end{array}$ & $\begin{array}{l}24.2 \% \\
(34)\end{array}$ & $\begin{array}{l}3.2 \% \\
(6)\end{array}$ & $\begin{array}{l}1.1 \% \\
(2)\end{array}$ & \\
\hline $\begin{array}{l}\text { Q11. I've been using alcohol or other drugs to } \\
\text { help me get through it. }\end{array}$ & $\begin{array}{l}75.8 \% \\
(141)\end{array}$ & $\begin{array}{l}19.9 \% \\
(37)\end{array}$ & $\begin{array}{l}3.8 \% \\
(7)\end{array}$ & $\begin{array}{l}.5 \% \\
(1)\end{array}$ & \\
\hline
\end{tabular}

Note: 1 = I haven't been doing this at all; 2 = I've been doing this a little bit; 3 = I've been doing this a medium amount; $4=$ I've been doing this a lot

Overall, participants indicated using the coping style of acceptance most commonly (87\%). The majority of participants coped with stress within pandemic conditions using a coping style of acceptance (87\%), active coping (66\%), positive reframing of the situation (65\%), planning (58\%), using emotional support (58\%), and religion (53\%). Less than half of the respondents used alternative approaches to coping 
with stress. These coping styles included using instrumental support (42\%) and humor (32\%). Less than a third of the respondents used coping styles of venting (27\%), self-blame (17\%), denial (8\%), behavioral disengagement $(6 \%)$, and substance abuse (4\%).

\section{DISCUSSION}

This study examined how SETs conducted their instructional work, interactions, and communication with students and parents, including legal requirements. Although classroom instruction shifted to primarily online teaching during distance learning (Cavanaugh \& Deweese, 2020), not all students appeared to be receiving instruction through these means. The most common online instructional approach used by SETs participating in this study was individual synchronous instruction. More than half of students also had instructional materials delivered to them. According to Smith \& Basham (2014), many fully online teachers rely on external programs provided through external vendors. Although these external programs may adhere to the federal guidelines of access for individuals with disabilities, this access doesn't extend to a student's cognitive level (Smith \& Basham, 2014). In effect, these digital tools may ignore the necessary specialized instruction a student with disabilities may need to mitigate gaps in developmental skills or knowledge (Greer, 2014). Findings from our study align with prior research on online instruction for students identified with disabilities. There is a continued need to consider differentiated online instruction and alternatives to online teaching to ensure student access to the required intensive intervention in special education programming in a distance learning format.

Students (and or parents) were more apt to interact with the special educators using digital resources such as an online platform or email. Participants also commonly used the phone for phone calls or texting. This necessary use of multiple modes for communication represents the essential need for interaction between students, parents, and teachers. Parents play a vital role in ensuring students in elementary through middle school engage in and complete online lessons (Currie-Rubin \& Smith, 2014). This partnership between online SETs and the family is critical to the success of online programming for students with disabilities (Coy, 2014; Currie-Rubin \& Smith, 2014).

Most participants conducted the required special education IEP team meetings using an online platform. Since these meetings are attended primarily by adult team members, the findings suggest online technology more accessible to the adults in a student team than the students themselves. Working towards mutual student goals requires careful interaction between parents and teachers, especially when implementing school interventions in the home (Bowen, 1999). Continued use of these technologies can enhance parent involvement in planning and decision-making by using a virtual meeting platform.

Developing a school culture of collaboration and opportunities for SETs to interact and work with other teachers supports SET retention (Benjamin \& Black, 2012; Bettini et al., 2018; Singh \& Billingsley, 1998). Regardless of the required sheltering in place, participants relied on their immediate colleagues as a resource for adapting to their work during distance learning. These findings confirm the value of collegial support to manage the work of SETs (Jones et al., 2013; Singh \& Billingsley, 1998) and suggest a need for routinely scheduled teamwork and collaboration across settings.

According to Cancio and colleagues (2018), the two highest-ranking indicators of stress for SETs were being tired from work and taking home problems from the school day. The COVID-19 pandemic required special educators to confront these stressors daily. Participants in our study appeared to accept these stressors, even within the extraordinary circumstances of a health pandemic. Overall, over half of the special educators participating in the coping portion of the study used positive methods, such as acceptance, active coping, positive reframing of the situation, planning, and using emotional support. One limitation of this study is the lack of information from participants who may have felt more overwhelmed with distance learning or SETs newer to the field. Since participants self-volunteered to complete the survey, most of the participants were SETs with more years of experience. However, findings from the study may convey information from SETs who can flexibly navigate their work and have stood the test of time to persist and respond effectively to the demands of their work. 


\section{CONCLUSION}

This study presents gaps in instructional technology and digital communication for students identified with special education needs. More research is needed to examine differentiated instruction for students requiring intensive intervention while using online or digital instructional technologies. The usefulness of specialized online instruction for students across the severity of disability requires further inquiry by examining alternative formats for online teaching or approaches in place of online instruction even when needing to teach from a distance. The participants highlighted the value of collegial support; however, more research is needed on scheduling and managing time for SETs to learn from one another and support one another. Lastly, the participants in this study reported an ability to positively conduct their work while dealing with the accompanying stressors, even under unique conditions. More research is needed to understand better how SETs effectively adapted to the rapid changes in their work and what approaches they found successful to cope with given the stressors during uncertain times.

\section{REFERENCES}

Bettini, E.A., Jones, N.D., Brownell, M.T., Conroy, M.A., \& Leite, W.L. (2018). Relationships between novice teachers' social resources and workload manageability. The Journal of Special Education, $52(2), 113-126$.

Billingsley, B., Carlson, E., \& Klein, S. (2004). The working conditions and induction support of early career special educators. Exceptional Children, 70(3), 333-347.

Cavanaugh, C., \& Deweese, A. (2020). Understanding the professional learning and support needs of educators during the initial weeks of pandemic school closures through search terms and content use. Journal of Technology and Teacher Education, 28(2), 233-238.

Carver, C.S. (1997). You want to measure coping but your protocol is too long: Consider the Brief COPE. International Journal of Behavioral Medicine, 4(1), 92-100.

Coy, K. (2014). Special educators' roles as virtual teachers. Teaching Exceptional Children, 46(5), 110116. https://doi.org/10.1177/0040059914530100

Currie-Rubin, R., \& Smith, S. (2014). Understanding the roles of families in virtual learning. Teaching Exceptional Children, 46(5), 117-126. https://doi.org/10.1177/0040059914530101

Gudmundsdottir, G.B., \& Hathaway, D.M. (2020). "We always make it work": Teachers' agency in the time of crisis. Journal of Technology and Teacher Education, 28(2), 239-250.

Hagaman, J.L., \& Casey, K.J. (2017). Teacher attrition in special education: Perspectives from the field. Teacher Education and Special Education, 41(4), 277-291.

Jones, N.D., Youngs, P., \& Frank, K.A. (2013). The role of school-based colleagues in shaping the commitment of novice special and general education teachers. Council for Exceptional Children, $79(3), 365-383$.

Minnesota Department of Education. (2020, June 20). Distance learning and implementation guidance. Retrieved from https://education.mn.gov/MDE/dse/health/covid19/supstucovid19/

Rice, M., \& Greer, D. (2014). Helping students with disabilities comprehend text in online coursework. Teaching Exceptional Children, 46(5), 93-101.

Singh, K., \& Billingsley, B.S. (1998). Professional support and its effects on teacher's commitment. The Journal of Educational Research, 91(4), 229-239.

Trust, T., Carpenter, J.P., Krutka, D.G., \& Kimmons, R. (2020). \#Remote teaching \& \#remote learning: Educator tweeting during the COVID-19 pandemic. Journal of Technology and Teacher Education, 28(2), 151-159.

UNESCO. (2020). COVID-19 Educational Disruption and Response. Retrieved from https://en.unesco.org/covid19/educationresponse

Vannest, K.J., \& Hagan-Burke, S. (2010). Teacher time in special education. Remedial and Special Education, 31(2), 126-142.

Whitaker, S.D. (2000). Mentoring beginning special education teachers and the relationship to attrition. Exceptional Children, 66(4), 546-566. 